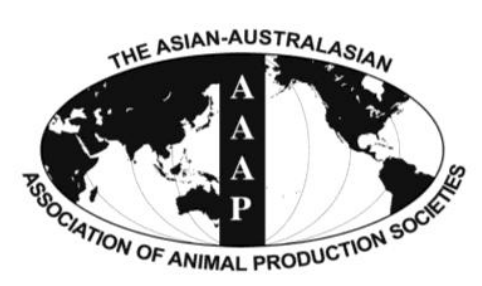

Open Access

Asian Australas. J. Anim. Sci.

Vol. 27, No. 6 : 806-817 June 2014

http://dx.doi.org/10.5713/ajas.2013.13542

www.ajas.info

pISSN 1011-2367 elSSN 1976-5517

\title{
Levels of Supplementation for Grazing Beef Heifers
}

\author{
Carla Heloisa Avelino Cabral*, Mario Fonseca Paulino ${ }^{1}$, Edenio Detmann ${ }^{1}$, \\ Sebastião de Campos Valadares Filho ${ }^{1}$, Lívia Vieira de Barros ${ }^{1}$, Ériton Egidio Lisboa Valente ${ }^{1}$, \\ Maristela de Oliveira Bauer ${ }^{2}$, and Carlos Eduardo Avelino Cabral ${ }^{3}$ \\ Departamento de Zootecnia, Universidade Federal de Viçosa (UFV), 36571-000, Viçosa, Minas Gerais, Brazil
}

\begin{abstract}
The objective of this experiment was to evaluate the effect of providing different levels of a supplement on the nutritional characteristics and productive performance of heifers on pasture during the rainy-dry transition and dry season in Brazil or tropical area. Thirty crossbred heifers with predominance of Zebu breed were used in a completely randomized experimental design. Treatments consisted of a mineral supplement and $0.5,1.0,1.5$, or $2.0 \mathrm{~kg} / \mathrm{animal} / \mathrm{d}$ of a protein supplement containing $300 \mathrm{~g}$ crude protein $(\mathrm{CP}) / \mathrm{kg}$ of dry matter $(\mathrm{DM})$. In the rainy-dry transition season there was quadratic effect of the protein supplementation $(\mathrm{p}<0.10)$ on daily weight gain (DWG). A linear relationship $(\mathrm{p}<0.10)$ was found between increasing supplement intake and intakes of DM, organic matter (OM), crude protein (CP), ether extract (EE), non fibrous carbohydrates (NFC) and total digestible nutrients (TDN). Coefficients of apparent digestibility of CP, EE, and NFC increased linearly $(\mathrm{p}<0.10)$ with increasing supplement levels, but there was no effect on the DM apparent digestibility ( $p>0.10)$; the microbial efficiency ( $\mathrm{CPmic} / \mathrm{kg}$ TDN) and the relationship of microbial nitrogen flow with nitrogen intake ( $\mathrm{g} / \mathrm{g}$ nitrogen intake) were negative linear profiles. In the dry season, the descriptive pattern least squares means showed a trend of stabilization of DWG from the supply of $0.98 \mathrm{~kg}$ of protein supplement; the intakes of DM, OM, CP, EE, NFC, and TDN showed increasing linear relationship $(\mathrm{p}<0.10)$ with protein supplement levels; the means of apparent digestibility coefficients of the different dietary fractions presented a linear-response-plateau (LRP); the microbial nitrogen flow (g/d) showed positive linear profile $(\mathrm{p}<0.10)$ for supplementation levels. It is concluded that supplementation improves the productive performance of grazing heifers and that $1.0 \mathrm{~kg} / \mathrm{d}$ of supplement per animal gives the maximum increment of weight gain. (Key Words: Nutritional Parameters, Protein Supplement, Weight Gain)
\end{abstract}

\section{INTRODUCTION}

The production of beef cattle in tropical environment is based on continuous grazing. In many parts of Brazil

\footnotetext{
* Corresponding Author: Carla Heloisa Avelino Cabral. Tel: +55 66-3410-4000, Fax: +55-66-3410-4000, E-mail: cabralcha@ hotmail.com

1 Departamento de Zootecnia, Researchers of INCT-CA, Universidade Federal de Viçosa (UFV), 36570-000, Viçosa, Minas Gerias, Brazil.

2 Departamento de Engenharia Rural, Universidade Federal do Espírito Santo (UFES), 29075-910, Alegre, Espírito Santo, Brazil.

3 Faculdade de Agronomia, Medicina Veterinária e Zootecnia, Universidade Federal de Mato Grosso (UFMT), 78060-900, Cuiabá, Mato Grosso, Brazil.

Submitted Sept. 3, 2013; Revised Nov. 8, 2013; Accepted Dec. 16, 2013
}

Brachiaria decumbens is the dominant pasture grass due to its adaptability in deficient soils. However to ensure reasonable cattle growth rates supplementation with protein and energy is necessary.

The low reproductive rates indicate inadequate nutrition and genetic quality of a herd (Rigolon et al., 2008). Among the factors that affect productive performance of cattle, nutrition is perhaps the one with the greatest impact (Santos and Amstalden, 1998). The age at puberty has an important impact on production, economic and reproductive efficiency cows. Age at puberty is dependent on the growth rate and development of the animal to support the endocrine mechanisms that resulting sexual maturity (Maquivar and Day, 2009).

The basic objective in the development of replacement females is to provide the appropriate amount of gain at the

Copyright (? 2014 by Asian-Australasian Journal of Animal Sciences This is an open-access article distributed under the terms of the Creative Commons Attribution Non-Commercial License (http://creativecommons.org/licenses/by-nc/3.0/), which permits unrestricted non-commercial use, distribution, and reproduction in any medium, provided the original work is properly cited. 
lowest possible cost (Semmelmann et al., 2001). It is noteworthy that some of the main reasons for the late onset of puberty in Zebu cattle are the seasonality of forage production, poor management of pasture and lack of feed supplementation during the growth of these animals (Sá Filho et al., 2008). Although Zebu cattle are later than European breeds, it may be possible to reduce the age at puberty of these animals through proper nutrient management and genetic improvement.

The use of supplements for grazing animals is a practice that can be used in pasture management strategy to increase the carrying capacity and animal performance. This requires sound knowledge on the subject, in order to achieve maximum technical and economic efficiency.

The objective of this work was to evaluate the effect of providing different levels of a supplement on the nutritional characteristics and productive performance of rearing heifers grazing Brachiaria decumbens Stapf. in the rainydry transition and dry season.

\section{MATERIAL AND METHODS}

All procedures involving animals were approved by Brazilian committee for care and experimentation.

\section{Animals, experiment design, and diets}

The experiment was conducted in the beef cattle sector at Universidade Federal de Viçosa - UFV, Viçosa, Brazil, in April to June 2009 (rainy-dry transition season) and July to September 2009 (dry season), in an area of 10 hectares.

The experimental area is located in a hilly area with 670 $\mathrm{m}$ of altitude and with an average precipitation of 1,300 mm annually. Throughout the days of measurement, average minimum and maximum temperatures were 14.6 and $25.0^{\circ} \mathrm{C}$ in, respectively. The rainfall for the period was 0.6 mm (Department of Agricultural Engineering - UFV).

Productive performance, voluntary intake, the nutritional characteristics (digestibility and microbial efficiency), the chemical composition of forage and supplements and pasture structure were evaluated during the experiment period.

Treatments consisted of mineral supplement (control treatment) and supply of $0.5,1.0,1.5$, and $2.0 \mathrm{~kg} / \mathrm{animal}$ (Table 1) of a supplement containing $300 \mathrm{~g}$ of crude protein (CP)/kg dry matter (DM) composed of soybean meal (200 $\mathrm{g} / \mathrm{kg})$, cottonseed meal (200 g/kg), corn (285 g/ $\mathrm{kg})$, sorghum $(285 \mathrm{~g} / \mathrm{kg})$ and urea:ammonium sulfate in 9:1 ratio $(30 \mathrm{~g} / \mathrm{kg})$.

The work was divided in two experimental periods: rainy-dry transition and dry season. Thirty crossbred heifers (predominately Zebu breed), $\sim 19$ months old and an average weight of $303 \pm 5 \mathrm{~kg}$ were used. They were vaccinated and wormed prior to the start of the trial.
Table 1. Chemical composition on the dry matter basis (g/kg DM)

\begin{tabular}{lccc}
\hline \multirow{2}{*}{ Item } & Protein & \multicolumn{2}{c}{$B$. decumbens } \\
\cline { 3 - 4 } & suplement & $\begin{array}{c}\text { Rainy-dry } \\
\text { transition }\end{array}$ & Dry season \\
\hline Dry matter & 888.7 & $351.3 \pm 12.0$ & $480.1 \pm 58.4$ \\
Crude protein & 304.9 & $71.7 \pm 6.3$ & $59.7 \pm 10.0$ \\
Ether extract & 28.6 & $12.4 \pm 1.5$ & $14.4 \pm 2.1$ \\
NDFap $^{2}$ & 188.2 & $666.0 \pm 9.6$ & $721.2 \pm 44.5$ \\
Organic matter $^{2}$ & 967.2 & $913.8 \pm 0.6$ & $919.1 \pm 5.4$ \\
NFC $^{3}$ & 499.9 & $163.7 \pm 7.9$ & $125.7 \pm 31.4$ \\
Lignin & 15.0 & $44.2 \pm 2.4$ & $59.4 \pm 5.7$ \\
\hline
\end{tabular}

Samples obtained by manual grazing simulation. Sample collected during digestibility trial.

${ }^{2}$ Neutral detergent fiber corrected for ash and protein.

${ }^{3}$ Non fibrous carbohydrates.

Water was provided ad libitum. The supplement was supplied at 10.00 am throughout the experimental period in covered troughs with access from both sides. The heifers given the supplement were fed $80 \mathrm{~g} / \mathrm{d}$ of a mineral supplement (composition on the basis of natural matter: dicalcium phosphate, $500.00 \mathrm{~g} / \mathrm{kg}$; sodium chloride, 477.75 $\mathrm{g} / \mathrm{kg}$; zinc sulfate, $14.00 \mathrm{~g} / \mathrm{kg}$, copper sulphate, $7.00 \mathrm{~g} / \mathrm{kg}$, cobalt sulphate, $0.50 \mathrm{~g} / \mathrm{kg}$, potassium iodide, $0.50 \mathrm{~g} / \mathrm{kg}$ and sodium selenite, $0.25 \mathrm{~g} / \mathrm{kg}$ ). The heifers in the control treatment had unrestricted access to the mineral supplement.

\section{Experimental procedures and sampling}

The animals were weighed at the beginning and end of the experiment (rainy-dry transition and dry season), after being fasted for liquids and solids for $14 \mathrm{~h}$, aiming to reduce the possible differences in the filling of the digestive tract. The total weight gain (TWG) was quantified by the difference between the final weight and initial weight at fast, with daily weight gain (DWG) the ratio between TWG and the number of experimental days.

On the fourteenth day of each experiment period, a collection was performed to determine DM total mass/ha (Table 2). The area to be sampled was delimited with a iron square $(0.5 \times 0.5 \mathrm{~m})$ in four random sites in each

Table 2. Herbage mass and morphological components mass of pasture during experiment periods

\begin{tabular}{lcc}
\hline \multirow{2}{*}{ Item } & \multicolumn{2}{c}{ Brachiaria decumbens $(\mathrm{kg} / \mathrm{d})$} \\
\cline { 2 - 3 } & $\begin{array}{c}\text { Rainy-dry } \\
\text { transition }\end{array}$ & Dry season \\
\hline Total dry matter mass & $4,717.5 \pm 340.3$ & $3,016.3 \pm 504.7$ \\
Potentially digestible & $2,742.3 \pm 259.0$ & $1,532.7 \pm 287.3$ \\
$\quad$ dry matter mass & $822.1 \pm 185.9$ & $238.1 \pm 76.3$ \\
Green leaf blade & $802.7 \pm 51.6$ & $601.4 \pm 104.0$ \\
Dry leaf blade & $1,558.7 \pm 259.9$ & $468.5 \pm 219.0$ \\
Green stem+sheath & $1,533.9 \pm 326.5$ & $1,708.4 \pm 146.3$ \\
Dry stem+sheath & & \\
\hline
\end{tabular}


experimental paddock. The samples were cut at ground level with scissors and then aliquots of each collected sample were taken, and composite samples were prepared for each paddock. An aliquot of the composite sample was separated into green leaf blade, dry leaf blade, green stem+sheath and dry stem+sheath to determine the mass of morphological components (Table 2).

Afterwards, the samples were weighed and dried in a forced circulation stove $\left(60^{\circ} \mathrm{C}\right)$, processed in a knife mill (1- and 2-mm) and placed in containers previously identified for further analysis. Quantification of DM content (Silva and Queiroz, 2002) was done.

Sampling for qualitative assessment of the pasture consumed by the animals was obtained via simulation manual (Johnson, 1978) also grazing on the fourteenth day of each experimental period. The samples were dried under forced ventilation $\left(60^{\circ} \mathrm{C}\right)$, processed in a knife mill (1- and $2-\mathrm{mm})$ and then packed in containers previously identified for analysis. During the digestibility trial grazing manual simulation was performed on the eighth day (42 of the productive performance).

Digestibility was measured from day 35 to 43 of the production trial. Each heifer was given 10 grams of chromic oxide marker per day (to estimate fecal excretion), introduced with the aid of an applicator through the esophagus at 9 am and 10 grams of titanium dioxide marker per animal per day mixed with protein supplement (to estimate supplement intake). The first six days of the marker intake were for adaptation and then the last three days were for collection of feces at $3 \mathrm{pm}, 7 \mathrm{am}$ and $10 \mathrm{am}$.

Feces were collected immediately after animal defecation or directly in the rectum, at quantities of approximately $200 \mathrm{~g}$, individually identified and dried in a forced air circulation oven $\left(60^{\circ} \mathrm{C}\right)$. After this period, the samples were processed in a knife mill (1- and 2-mm) and samples composed of the three days of collection were made.

On the 9th day of the digestibility trial, "spot" urine sample $(10 \mathrm{~mL})$ was collected from animal spontaneous urination four hours after supplement supply (Valadares et al., 1999). After collection, urine samples were diluted in 40 $\mathrm{mL}$ of $\mathrm{H}_{2} \mathrm{SO}_{4}(0.036 \mathrm{~N})$ and stored at $-20^{\circ} \mathrm{C}$ for subsequent quantification of the levels of creatinine, urea and purine derivatives.

\section{Chemical analysis}

Samples of forage, feces and ingredients used to produce the supplement, processed in a 1-mm sieve mil, were evaluated for $\mathrm{DM}$, organic matter (OM), CP, ether extract (EE) and lignin $\left(\mathrm{H}_{2} \mathrm{SO}_{4} 72 \% \mathrm{w} / \mathrm{w}\right)$ according to the techniques described by Silva and Queiroz (2002); neutral detergent fiber (NDF) was evaluated according to techniques described by Mertens (2002), using thermostable $\alpha$-amylase, but omitting the use of sodium sulfite; corrections for protein and ash in the NDF followed the procedures described by Licitra et al. (1996) and Mertens (2002), respectively.

The levels of non-fibrous carbohydrates (NFC) were obtained according to the equation proposed by Detmann and Valadares Filho (2010):

$$
\mathrm{NFC}=100-[\mathrm{MM}+\mathrm{EE}+\mathrm{NDFap}+(\mathrm{CP}-\mathrm{CPu}+\mathrm{U})]
$$

In which: $\mathrm{NFC}=$ non-fibrous carbohydrates; $\mathrm{MM}=$ mineral matter content; $\mathrm{EE}=$ ether extract content; NDFap $=$ neutral detergent fiber corrected for ash and protein content; $\mathrm{CP}=$ crude protein content; $\mathrm{CPu}=$ urea crude protein content; and $\mathrm{U}=$ urea content. All other items are expressed as DM \%.

Feces samples were analyzed for the levels of titanium dioxide according to the colorimetric technique described by Titgemeyer et al. (2001) and chromic oxide in atomic absorption spectrophotometer as described by Williams et al. (1962). Feces excretion was estimated through the relationship between dose and feces concentration of chromic oxide.

To estimate the voluntary feed intake, indigestible neutral detergent fiber (iNDF) was used according to Detmann et al. (2001), quantified by in situ incubation procedures with Ankon bags (F57) for $288 \mathrm{~h}$ in samples processed at 2-mm. The estimate was done by the following equation:

$$
\mathrm{IIpDM}=\frac{[(\mathrm{FE} \times \mathrm{iFC})-\mathrm{iS}]}{\mathrm{iFoC}}
$$

In which: IIpDM = individual intake of pasture dry matter $(\mathrm{kg} / \mathrm{d}) ; \mathrm{FE}=$ feces excretion $(\mathrm{kg} / \mathrm{d}) ; \mathrm{iFC}=\mathrm{iNDF}$ feces concentration $(\mathrm{kg} / \mathrm{kg})$; iS = iNDF intake from the supplement $(\mathrm{kg} / \mathrm{d})$ and $\mathrm{iFoC}=\mathrm{iNDF}$ forage concentration $(\mathrm{kg} / \mathrm{kg})$.

Estimation of individual supplement intake was obtained by the following equation:

$$
\text { SupII }=\frac{(\mathrm{FE} \times \mathrm{iFC})}{\mathrm{iFG}} \times \operatorname{SupFG}
$$

In which: SupII = supplement individual intake $(\mathrm{g} / \mathrm{d})$; $\mathrm{FE}=$ feces excretion $(\mathrm{g} / \mathrm{d}) ; \mathrm{iFC}=$ titanium dioxide feces concentration $(\mathrm{g} / \mathrm{g}) ; \mathrm{iFG}=$ titanium dioxide in the supplement fed to the group of animals $(\mathrm{g} / \mathrm{d})$; SupFG = supplement amount fed to the animals $(\mathrm{g} / \mathrm{d})$.

Total DM intake $(\mathrm{kg} / \mathrm{d})$ was estimated by summing IIpDM and SupII.

Forage samples collected for evaluation of moment mass at a given experimental period were evaluated for DM, 
NDF, and iNDF as described above. The percentage of potentially digestible DM (DMpd) in the forage in each experiment period was estimated according to Paulino et al. (2008):

$$
\mathrm{DMpd}=0.98 \times(100-\mathrm{NDF})+(\mathrm{NDF}-\mathrm{iNDF})
$$

In which: $\mathrm{DMpd}=$ forage content of potentially digestible DM (DM \%); 0.98 = cell content true digestible coefficient; and NDF and $\mathrm{iNDF}=$ forage content of NDF and iNDF, respectively (DM \%).

Urine samples, after thawing, were analyzed for levels of creatinine, according to the modified method of Jaffé; uric acid, by enzymatic-colorimetric with clearing factor of lipid; allantoin, according to the colorimetric method described by Chen and Gomes (1992), and urea by the method Urease/GLDH.

The total volume of urine was estimated through the relationship between daily excretion of creatinine in function of the body weight and urine creatinina concentration. Creatinine excretion per body weight unit was obtained according to equation (Chizzotti et al., 2006):

\section{$\mathrm{CE}=32.27-0.01093 \times \mathrm{BW}$}

In which: $\mathrm{CE}=$ creatine daily excretion $(\mathrm{mg} / \mathrm{kg} \mathrm{BW})$; and $\mathrm{BW}=$ body weight $(\mathrm{kg})$.

Urea daily urinary excretion was estimated by multiplying its concentration in urine spot samples and the urinary volume estimated value. The excretion of purine derivatives was calculated by the sum of allantoin and uric acid excreted in the urine.

The purines absorbed were calculated from the excretion of purine derivatives by the equation (Barbosa et al., 2011):

$$
\mathrm{AP}=\frac{\mathrm{PD}-0.301 \times \mathrm{WB}^{0.75}}{0.80}
$$

In which: $\mathrm{AP}=$ absorbed purines $(\mathrm{mmol} / \mathrm{d}) ; \mathrm{PD}=$ purine derivatives excretion $(\mathrm{mmol} / \mathrm{d}) ; 0.301=$ the endogenous purine derivatives excretion (mmol) in the urine per unit of metabolic size $\left(\mathrm{BW}^{0.75}\right)$; and $0.80=$ the recovery of absorbed purines as purine derivatives in the urine ( $\mathrm{mmol} / \mathrm{mmol})$.

Rumen synthesis of microbial nitrogen compounds was estimated in function of the AP using the equation described by Chen and Gomes (1992):

$$
\mathrm{N}_{m i c}=\frac{70 \times \mathrm{AP}}{0.83 \times \mathrm{R} \times 1,000}
$$

In which: $\mathrm{N}_{\text {mic }}=$ microbial nitrogen compounds flow in the small intestine $(\mathrm{g} / \mathrm{d}) ; \mathrm{R}=\mathrm{N}_{\mathrm{RNA}}: \mathrm{N}_{\mathrm{TOTAL}}$ ratio in the microorganisms $(\mathrm{mg} / \mathrm{mg}) ; 70=$ nitrogen content in the purines $(\mathrm{mg} / \mathrm{mmol})$; and $0.83=$ intestine digestibility of microbial purine $(\mathrm{mg} / \mathrm{mg})$. The 0.134 ratio of $\mathrm{N}_{\mathrm{RNA}}: \mathrm{N}_{\mathrm{TOTAL}}$ was used, according to Valadares et al. (1999).

\section{Statistical analysis}

The experiment was analyzed in a completely randomized design with five treatments (mineral supplement and four levels of supply of protein supplement). After the analysis of variance, treatments were compared by means of orthogonal decomposition of the sum of squares of the treatments in linear, quadratic, cubic and fourth degree order effects related to the effect of level of supplementation, with subsequent adjustment of the linear regression equations.

Statistical procedures were conducted by means of PROC GLM of SAS (Statistical Analysis System, version 9.2), adopting 0.10 as the critical level of probability of type I error and body weight as a covariate.

\section{RESULTS}

The average DM mass of $4,717 \mathrm{~kg} / \mathrm{ha}$ in the rainy-dry transition period (Table 2) which corresponded to $72.8 \mathrm{~g} / \mathrm{kg}$ of $\mathrm{BW}$ is within the range from 70 to $110 \mathrm{~g} / \mathrm{kg} \mathrm{BW}$ of forage supply to obtain high DWG without affecting gain per area (Barbosa et al., 2006).

In the rainy-dry transition, an average of $2,742 \mathrm{~kg} / \mathrm{ha}$ of DMpd (Table 2), which corresponded to a supply of 42.4 $\mathrm{g} / \mathrm{kg} \mathrm{BW}$ was observed and it is within the recommendation of Paulino et al. (2004) of 40 to $50 \mathrm{~g} / \mathrm{kg} \mathrm{BW}$ of animals of DMpd of pasture for a satisfactory performance. However, in the dry season the DMpd fraction was $1,533 \mathrm{~kg} / \mathrm{ha}(21.7$ $\mathrm{g} / \mathrm{kg} \mathrm{BW}$ ) (Table 2), which is half of the minimum recommended by this author.

Daily weight gain presented a quadratic effect $(\mathrm{p}<0.10)$ for the different levels of protein supplementation (Table 3). The maximum DWG of $489.4 \mathrm{~g}$ occurred for the supply level of $1.05 \mathrm{~kg}$ of supplement per animal per day and performance was approximately $32 \%$ higher than that of heifers fed only mineral supplement.

The DWG had a quadratic effect $(\mathrm{p}<0.10)$ for levels of supplementation (Table 3) in the dry season. However, by analyzing the standard description of the least square means, a decrease in efficiency of weight gain ( $\mathrm{g} / \mathrm{kg}$ of supplement) was observed when level of supplement supply was increased (Table 4), with a tendency to stabilize DWG.

Increasing linear effect $(\mathrm{p}<0.10)$ of the levels of protein supplement supply were observed for intakes of DM, OM, $\mathrm{CP}, \mathrm{EE}, \mathrm{NFC}$, and TDN, and there was no effect $(\mathrm{p}>0.10)$ for intakes of pasture DM (PDM), pasture OM (POM), NDFap and iNDF (Tables 5 and 6). 
Table 3. Least square means, coefficient of variation (CV) and significance of effects for productive performance

\begin{tabular}{|c|c|c|c|c|c|c|c|c|c|c|}
\hline \multirow{2}{*}{ Item } & \multicolumn{5}{|c|}{ Protein supplement $(\mathrm{kg} / \mathrm{d})$} & \multirow{2}{*}{$\begin{array}{l}\mathrm{CV} \\
(\%)\end{array}$} & \multicolumn{4}{|c|}{ p-value ${ }^{1}$} \\
\hline & 0 & 0,5 & 1,0 & 1,5 & 2,0 & & $\mathrm{~L}$ & $\mathrm{Q}$ & $\mathrm{C}$ & $\mathrm{F}$ \\
\hline \multicolumn{11}{|l|}{ Rainy-dry transition season } \\
\hline Initial body weight $(\mathrm{kg})$ & 301 & 297 & 307 & 301 & 307 & & & & & \\
\hline Final body weight $^{2}(\mathrm{~kg})$ & 331 & 339 & 339 & 341 & 332 & 1.6 & 0.5225 & 0.0029 & 0.5804 & 0.3023 \\
\hline Daily weight gain ${ }^{3}(\mathrm{~g})$ & 369 & 464 & 464 & 494 & 381 & 15.1 & 0.5225 & 0.0029 & 0.5804 & 0.3023 \\
\hline \multicolumn{11}{|l|}{ Dry season } \\
\hline Initial body weight $(\mathrm{kg})$ & 337 & 339 & 341 & 340 & 339 & & & & & \\
\hline Final body weight ${ }^{4}(\mathrm{~kg})$ & 334 & 350 & 357 & 359 & 362 & 1.6 & 0.0001 & 0.0020 & 0.2468 & 0.9880 \\
\hline Daily weight gain ${ }^{5}(\mathrm{~g})$ & -61 & 123 & 204 & 232 & 261 & 45.0 & 0.0001 & 0.0020 & 0.2468 & 0.9880 \\
\hline
\end{tabular}

${ }^{1} \mathrm{~L}, \mathrm{Q}, \mathrm{C}$, and F = Linear, quadratic, cubic and fourth degree, respectively.

${ }^{2} \hat{\mathrm{Y}}=331.0+19.4 \mathrm{x}-9.2571 \mathrm{x}^{2}\left(\mathrm{R}^{2}=0.8810\right) \cdot{ }^{3} \hat{\mathrm{Y}}=369.5+228.1 \mathrm{x}-108.4445 \mathrm{x}^{2}\left(\mathrm{R}^{2}=0.8975\right)$

${ }^{4} \hat{Y}=334.9+30.3 x-8.7429\left(R^{2}=0.9830\right) .{ }^{5} \hat{Y}=-49.4+352.6 x-101.1195 x^{2}\left(R^{2}=0.9838\right)$.

Table 4. Relationship between performance and supplement intake, considering the experimental conditions in this study, in the dry season

\begin{tabular}{lcc}
\hline $\begin{array}{l}\text { Range of supplement intake } \\
(\mathrm{kg} / \mathrm{d})\end{array}$ & $\begin{array}{c}\text { Incremented weight gain } \\
\mathrm{G}(\mathrm{g})\end{array}$ & $\begin{array}{c}\text { Weight gain efficiency } \\
\text { g/kg supplement }\end{array}$ \\
\hline $0-0.5$ & 189 & 368 \\
$0.5-1.0$ & 80.8 & 162 \\
$1.0-1.5$ & 28.2 & 56 \\
$1.5-2.0$ & 29.5 & 59 \\
\hline
\end{tabular}

Table 5. Least square means, coefficients of variation (CV) and significance of effects for voluntary intake in the rainy-dry transition season

\begin{tabular}{|c|c|c|c|c|c|c|c|c|c|c|}
\hline \multirow{2}{*}{ Item } & \multicolumn{5}{|c|}{ Protein supplement $(\mathrm{kg} / \mathrm{d})$} & \multirow{2}{*}{$\begin{array}{l}\mathrm{CV} \\
(\%)\end{array}$} & \multicolumn{4}{|c|}{ p-value $^{1}$} \\
\hline & 0 & 0.5 & 1.0 & 1.5 & 2.0 & & $\mathrm{~L}$ & Q & $\mathrm{C}$ & $\mathrm{F}$ \\
\hline & \multicolumn{10}{|c|}{ 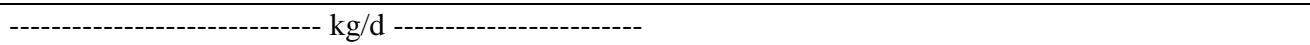 } \\
\hline Dry matter ${ }^{2}$ & 6.757 & 6.756 & 7.502 & 7.837 & 8.005 & 12.5 & 0.0060 & 0.9598 & 0.4502 & 0.6604 \\
\hline Pasture dry matter & 6.757 & 6.351 & 6.591 & 6.412 & 6.205 & 13.1 & 0.3491 & 0.9876 & 0.5432 & 0.6182 \\
\hline Organic matter ${ }^{3}$ & 6.178 & 6.199 & 6.907 & 7.241 & 7.414 & 13.5 & 0.0036 & 0.9584 & 0.4462 & 0.6630 \\
\hline Pasture organic matter & 6.178 & 5.807 & 6.027 & 5.862 & 5.673 & 13.1 & 0.3491 & 0.9876 & 0.5432 & 0.6182 \\
\hline Crude protein ${ }^{4}$ & 0.504 & 0.598 & 0.770 & 0.913 & 1.012 & 13.1 & $<0.0001$ & 0.9109 & 0.3460 & 0.7911 \\
\hline Ether extract ${ }^{5}$ & 0.092 & 0.098 & 0.116 & 0.128 & 0.136 & 12.5 & $<0.0001$ & 0.9367 & 0.3915 & 0.7105 \\
\hline Non fibrous carbohidrates ${ }^{6}$ & 1.198 & 1.328 & 1.624 & 1.849 & 2.000 & 12.6 & $<0.0001$ & 0.9254 & 0.3687 & 0.7428 \\
\hline NDFap & 4.382 & 4.195 & 4.446 & 4.426 & 4.363 & 12.9 & 0.7926 & 0.9789 & 0.5115 & 0.6294 \\
\hline iNDF & 1.445 & 1.372 & 1.441 & 1.420 & 1.389 & 13.0 & 0.7880 & 0.9828 & 0.5252 & 0.6242 \\
\hline $\mathrm{dNDF}$ & 2.915 & 2.782 & 2.952 & 2.822 & 2.772 & 14.3 & 0.6588 & 0.8372 & 0.6891 & 0.4959 \\
\hline Total digestible nutrients ${ }^{7}$ & 3.988 & 4.056 & 4.664 & 5.026 & 5.142 & 14.0 & 0.0005 & 0.8804 & 0.3501 & 0.7232 \\
\hline \multirow[t]{2}{*}{$\mathrm{TDN}: \mathrm{CP}^{8}$} & 7.890 & 6.788 & 6.057 & 5.488 & 5.077 & 5.2 & $<0.0001$ & 0.0050 & 0.6188 & 0.8529 \\
\hline & \multicolumn{10}{|c|}{--1.--- g/kg of body weight } \\
\hline Dry matter ${ }^{9}$ & 20.14 & 20.23 & 22.00 & 23.04 & 23.89 & 12.4 & 0.0071 & 0.8507 & 0.6006 & 0.7534 \\
\hline Pasture dry matter & 20.14 & 19.04 & 19.33 & 18.83 & 18.48 & 12.7 & 0.2708 & 0.8481 & 0.6992 & 0.7089 \\
\hline Organic matter ${ }^{10}$ & 18.42 & 18.56 & 20.26 & 21.29 & 22.13 & 12.5 & 0.0044 & 0.8511 & 0.5965 & 0.7561 \\
\hline Pasture organic matter & 18.42 & 17.41 & 17.68 & 17.21 & 16.90 & 12.7 & 0.2708 & 0.8480 & 0.6994 & 0.7089 \\
\hline NDFap & 13.06 & 12.57 & 13.04 & 13.00 & 13.00 & 12.5 & 0.8833 & 0.8478 & 0.6656 & 0.7210 \\
\hline $\mathrm{NDFi}$ & 4.31 & 4.12 & 4.23 & 4.17 & 4.14 & 12.6 & 0.6843 & 0.8478 & 0.6801 & 0.7155 \\
\hline
\end{tabular}

NDFap $=$ Neutral detergent fiber correct for ash and protein; iNDF = Indigestible neutral detergent fiber; dNDF = Digested neutral detergent fiber.

${ }^{1} \mathrm{~L}, \mathrm{Q}, \mathrm{C}$, and $\mathrm{F}=$ Linear, quadratic, cubic and fourth degree, respectively.

${ }^{2} \hat{Y}=6.7+0.7150 x\left(r^{2}=0.9193\right) .{ }^{3} \hat{Y}=6.1+0.7028 x\left(r^{2}=0.9282\right) .{ }^{4} \hat{Y}=0.5+0.2661 x\left(r^{2}=0.9907\right) .{ }^{5} \hat{Y}=0.09+0.0236 x\left(r^{2}=0.9783\right)$.

${ }^{6} \hat{\mathrm{Y}}=1.18+0.4248 \mathrm{x}\left(\mathrm{r}^{2}=0.9857\right) .{ }^{7} \hat{\mathrm{Y}}=3.9+0.6559 \mathrm{x}\left(\mathrm{r}^{2}=0.9370\right) .{ }^{8} \hat{\mathrm{Y}}=7.9-2.3 \mathrm{x}+0.4411 \mathrm{x}^{2}\left(\mathrm{R}^{2}=0.9990\right)$.

${ }^{9} \hat{Y}=19.8+2.0533 x\left(r^{2}=0.9530\right) .{ }^{10} \hat{Y}=18.1+2.0286 x\left(r^{2}=0.9587\right)$. 
Table 6. Least square means, coefficients of variation (CV) and significance of effects for voluntary intake in the dry season

\begin{tabular}{|c|c|c|c|c|c|c|c|c|c|c|}
\hline \multirow{2}{*}{ Item } & \multicolumn{5}{|c|}{ Protein supplement $(\mathrm{kg} / \mathrm{d})$} & \multirow{2}{*}{$\begin{array}{l}\mathrm{CV} \\
(\%)\end{array}$} & \multicolumn{4}{|c|}{ p-value ${ }^{1}$} \\
\hline & 0 & 0.5 & 1.0 & 1.5 & 2.0 & & $\mathrm{~L}$ & Q & $\mathrm{C}$ & $\mathrm{F}$ \\
\hline & \multicolumn{10}{|c|}{ 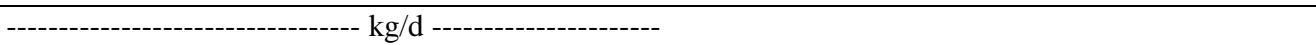 } \\
\hline Dry matter ${ }^{2}$ & 4.755 & 5.073 & 5.561 & 5.820 & 6.325 & 14.5 & 0.0009 & 0.9073 & 0.9412 & 0.7502 \\
\hline Pasture dry matter & 4.755 & 4.576 & 4.601 & 4.320 & 4.345 & 14.0 & 0.1994 & 0.9184 & 0.9003 & 0.6077 \\
\hline Organic matter ${ }^{3}$ & 4.411 & 4.730 & 5.195 & 5.461 & 5.948 & 14.5 & 0.0006 & 0.9046 & 0.9401 & 0.7676 \\
\hline Pasture organic matter & 4.411 & 4.248 & 4.270 & 4.008 & 4.031 & 14.0 & 0.1986 & 0.9208 & 0.8960 & 0.6094 \\
\hline Crude protein ${ }^{4}$ & 0.287 & 0.429 & 0.571 & 0.720 & 0.869 & 20.0 & $<0.0001$ & 0.9074 & 0.9949 & 0.9766 \\
\hline Ether extract ${ }^{5}$ & 0.080 & 0.091 & 0.105 & 0.115 & 0.130 & 15.4 & $<0.0001$ & 0.9010 & 0.9596 & 0.8370 \\
\hline Non fibrous carbohidrates ${ }^{6}$ & 0.526 & 0.754 & 0.987 & 1.226 & 1.468 & 19.3 & $<0.0001$ & 0.9063 & 0.9991 & 0.9931 \\
\hline NDFap & 3.517 & 4.479 & 3.584 & 3.478 & 3.587 & 13.9 & 0.8274 & 0.9125 & 0.9108 & 0.6468 \\
\hline iNDF & 1.250 & 1.220 & 1.243 & 1.188 & 1.211 & 13.9 & 0.6165 & 0.9150 & 0.9056 & 0.6283 \\
\hline dNDF & 2.153 & 2.228 & 2.292 & 2.152 & 2.304 & 14.2 & 0.5846 & 0.9174 & 0.4645 & 0.5277 \\
\hline \multirow[t]{2}{*}{ Total digestible nutrients ${ }^{7}$} & 2.526 & 3.029 & 3.633 & 3.771 & 4.346 & 15.4 & $<0.0001$ & 0.6951 & 0.6277 & 0.4270 \\
\hline & \multicolumn{10}{|c|}{$\mathrm{g} / \mathrm{kg}$ of body weigh - } \\
\hline Dry matter ${ }^{8}$ & 13.28 & 14.06 & 15.11 & 15.70 & 17.31 & 11.3 & 0.0002 & 0.6486 & 0.7302 & 0.7043 \\
\hline Pasture dry matter ${ }^{9}$ & 13.28 & 12.71 & 12.51 & 11.66 & 11.91 & 11.4 & 0.0486 & 0.6527 & 0.6911 & 0.5716 \\
\hline Organic matter ${ }^{10}$ & 12.33 & 13.11 & 14.12 & 14.73 & 16.27 & 11.3 & 0.0001 & 0.6530 & 0.7311 & 0.7233 \\
\hline Pasture organic matter ${ }^{11}$ & 12.33 & 11.79 & 11.61 & 10.83 & 11.06 & 11.4 & 0.0489 & 0.6445 & 0.7027 & 0.5731 \\
\hline NDFap & 9.83 & 9.66 & 9.75 & 9.39 & 9.83 & 11.1 & 0.8493 & 0.6399 & 0.7048 & 0.6064 \\
\hline NDFi & 3.50 & 3.39 & 3.38 & 3.21 & 3.32 & 11.2 & 0.2850 & 0.6414 & 0.7032 & 0.5897 \\
\hline
\end{tabular}

NDFap = Neutral detergent fiber correct for ash and protein; iNDF = Indigestible neutral detergent fiber; $\mathrm{dNDF}=$ Digested neutral detergent fiber.

${ }^{1} \mathrm{~L}, \mathrm{Q}, \mathrm{C}$, and $\mathrm{F}=$ Linear, quadratic, cubic and fourth degree, respectively.

${ }^{2} \hat{Y}=4.73+0.7773 x\left(r^{2}=0.9914\right) .{ }^{3} \hat{Y}=4.39+0.7610 x\left(r^{2}=0.9930\right) .{ }^{4} \hat{Y}=0.28+0.2908 x\left(r^{2}=0.9998\right) .{ }^{5} \hat{Y}=0.0799+0.0248 x\left(r^{2}=0.9983\right)$.

${ }^{6} \hat{\mathrm{Y}}=0.52+0.4711 \mathrm{x}\left(\mathrm{r}^{2}=0.9998\right) .{ }^{7} \hat{\mathrm{Y}}=2.59+0.8763 \mathrm{x}\left(\mathrm{r}^{2}=0.9748\right) .{ }^{8} \hat{\mathrm{Y}}=13.16+1.9400 \mathrm{x}\left(\mathrm{r}^{2}=0.9758\right) .{ }^{9} \hat{\mathrm{Y}}=13.18-0.7567 \mathrm{x}\left(\mathrm{r}^{2}=0.8604\right)$.

${ }^{10} \hat{\mathrm{Y}}=12.22+1.8975 \mathrm{x}\left(\mathrm{r}^{2}=0.9789\right) .{ }^{11} \hat{\mathrm{Y}}=12.23-0.7013 \mathrm{x}\left(\mathrm{r}^{2}=0.8608\right)$.

The Figure 2 shows the relationship TDN/CP according to the level of supplement intake by heifers in different treatments in the rainy-dry transition season.

In the rainy-dry transition season the levels of suplementation had an increasing linear effect $(p<0.10)$ on coefficients of apparent digestibility of OM, CP, EE, NFC, and TDN while apparent digestibility of DM was not different $(\mathrm{p}>0.10)$ among treatments (Table 7).

In the dry season there was a quadratic effect $(p<0.10)$ of levels of supplement on digestibility of DM, OM, CP, EE, NFCm, and TDN (\% DM) but there was no effect on the digestibility of NDFap ( $>>0.10)$ (Table 7).

However, when evaluating the means of digestibility of the different fractions, a linear-response-plateau (LRP) standard was suggest. The adjustment of these functions evidenced (Table 8) the increase $(\mathrm{p}<0.10)$ of digestibilities of DM, OM, CP, EE, NFC, and TDN with limits close to $1.1,0.9,0.8,0.8,1.3$, and $1.1 \mathrm{~kg}$ of protein supplement per day, respectively. From these levels, the mentioned variables remained unchanged.

It is noteworthy that by calculating the means of the levels of the protein supplement which constituted the digestibility plateau of the different feed fractions, the average value of $0.98 \mathrm{~kg}$ which corresponds to the point where DWG becomes equivalent to $\mathrm{DWG}_{\mathrm{Max}}$ is found.

The ureic nitrogen urinary excretion (UNUE, g/d) showed a positive linear $(\mathrm{p}<0.10)$ profile for levels of supplementation (Table 9).

There was no effect of supplementation levels on the flow of microbial nitrogen compounds (FMNC, g/d) ( $p>0.10)$, but the microbial synthesis efficiency (MSE, g microbial $\mathrm{CP} / \mathrm{kg}$ TDN consumed), and the flow of microbial nitrogen compounds in relation to nitrogen intake (FMNC/NI, g/g nitrogen intake) showed negative linear profiles $(\mathrm{p}<0.10)$ in the rainy-dry season (Table 9$)$.

There was an increasing linear effect $(p<0.10)$ of the levels of protein supplement supply on FMNC in the dry season (Table 9).

The MSE and the FMNC/NI presented quadratic profiles $(p<0.10)$ in function of the different treatments in the dry season (Table 9). However, when evaluating the least squares mean, the standard $L R P$ was observed for MSE and FMNC/NI (Table 10). Functions adjustment evidenced the linear decreasing profile of MSE and FMNC/NI up to the values of 116.9 and 0.65 , respectively. From these points, the variables remained unchanged.

\section{DISCUSSION}

Forage is the basis of feeding for pasture cattle production system, in which the forage is selected and collected by the animal itself. For the maximum productive 
Table 7. Digestibility coefficients and total digestible nutrients in heifers according to different treatments

\begin{tabular}{|c|c|c|c|c|c|c|c|c|c|c|}
\hline \multirow{2}{*}{ Item } & \multicolumn{5}{|c|}{ Protein supplement $(\mathrm{kg} / \mathrm{d})$} & \multirow{2}{*}{$\begin{array}{l}\text { CV } \\
(\%)\end{array}$} & \multicolumn{4}{|c|}{ p-value ${ }^{1}$} \\
\hline & 0 & 0.5 & 1 & 1.5 & 2 & & $\mathrm{~L}$ & $\mathrm{Q}$ & $\mathrm{C}$ & $\mathrm{F}$ \\
\hline \multicolumn{11}{|l|}{ Rainy-dry transition season } \\
\hline Dry matter & 60.95 & 61.31 & 62.21 & 63.12 & 61.78 & 3.8 & 0.2580 & 0.3474 & 0.3616 & 0.8336 \\
\hline Organic matter ${ }^{2}$ & 64.34 & 65.03 & 66.06 & 67.39 & 66.75 & 3.2 & 0.0133 & 0.4671 & 0.4002 & 0.7561 \\
\hline Crude protein ${ }^{3}$ & 51.02 & 55.20 & 61.45 & 62.28 & 64.62 & 5.7 & $<0.0001$ & 0.1017 & 0.9082 & 0.2444 \\
\hline Ether extract ${ }^{4}$ & 7.31 & 10.91 & 31.73 & 36.40 & 50.35 & 33.4 & $<0.0001$ & 0.7712 & 0.5994 & 0.1250 \\
\hline Non fibrous carbohydrates ${ }^{5}$ & 65.76 & 71.29 & 71.07 & 74.36 & 77.23 & 5.1 & $<0.0001$ & 0.7517 & 0.2713 & 0.3012 \\
\hline NDFap $^{6}$ & 65.95 & 66.36 & 66.32 & 66.91 & 63.37 & 3.8 & 0.0694 & 0.0805 & 0.1799 & 0.5499 \\
\hline Total digestible nutrients ${ }^{7}$ & 58.96 & 60.04 & 62.10 & 64.02 & 64.13 & 3.2 & $<0.0001$ & 0.5017 & 0.2938 & 0.9351 \\
\hline \multicolumn{11}{|l|}{ Dry season } \\
\hline Dry matter ${ }^{8}$ & 52.74 & 56.85 & 62.15 & 61.91 & 64.01 & 4.0 & $<0.0001$ & 0.0363 & 0.7507 & 0.1801 \\
\hline Organic matter $^{9}$ & 56.18 & 62.65 & 66.76 & 66.72 & 68.10 & 2.6 & $<0.0001$ & $<0.0001$ & 0.1462 & 0.2688 \\
\hline Crude protein ${ }^{10}$ & 29.98 & 52.53 & 64.55 & 65.67 & 68.56 & 9.9 & $<0.0001$ & $<0.0001$ & 0.1092 & 0.5742 \\
\hline Ether extract ${ }^{11}$ & 22.07 & 51.86 & 67.12 & 69.91 & 75.52 & 13.6 & $<0.0001$ & $<0.0001$ & 0.1369 & 0.6377 \\
\hline Non fibrous carbohydrates ${ }^{12}$ & 47.18 & 59.88 & 78.20 & 78.88 & 79.82 & 9.8 & $<0.0001$ & 0.0010 & 0.5390 & 0.1206 \\
\hline NDFap & 61.20 & 63.88 & 63.48 & 62.72 & 63.80 & 3.4 & 0.1724 & 0.3115 & 0.1004 & 0.9449 \\
\hline Total digestible nutrients ${ }^{13}$ & 53.14 & 59.38 & 64.50 & 64.82 & 67.56 & 3.3 & $<0.0001$ & 0.0024 & 0.2008 & 0.1815 \\
\hline
\end{tabular}

NDFap $=$ Neutral detergent fiber correct for ash and protein.

${ }^{1} \mathrm{~L}, \mathrm{Q}, \mathrm{C}$, and $\mathrm{F}=$ Linear, quadratic, cubic and fourth degree, respectively.

${ }^{2} \hat{Y}=64.49+1.4357 x\left(r^{2}=0.8378\right) .{ }^{3} \hat{Y}=52.06+6.8548 x\left(r^{2}=0.9294\right) .{ }^{4} \hat{Y}=4.21+22.1974 x\left(r^{2}=0.9775\right) .{ }^{5} \hat{Y}=66.75+5.2020 x\left(r^{2}=0.9241\right)$.

${ }^{6} \hat{Y}=65.67+3.23 x-2.0771 x^{2}\left(R^{2}=0.7621\right) .{ }^{7} \hat{Y}=58.99+2.8640 x\left(r^{2}=0.9494\right) .{ }^{8} \hat{Y}=52.65+10.9818 x-2.7309 x^{2}\left(R^{2}=0.9628\right)$.

${ }^{9} \hat{\mathrm{Y}}=56.46+13.7756 \mathrm{x}-4.0951 \mathrm{x}^{2}\left(\mathrm{R}^{2}=0.9767\right) .{ }^{10} \hat{\mathrm{Y}}=31.12+45.5171 \mathrm{x}-13.1065 \mathrm{x}^{2}\left(\mathrm{R}^{2}=0.9826\right) .{ }^{11} \hat{\mathrm{Y}}=23.23+61.8934 \mathrm{x}-18.1728 \mathrm{x}^{2}\left(\mathrm{R}^{2}=0.9928\right)$

${ }^{12} \hat{Y}=46.03+40.5229 x-11.8148 x^{2}\left(R^{2}=0.9692\right) .{ }^{13} \hat{Y}=53.35+13.5916 x-3.3680 x^{2}\left(R^{2}=0.9774\right)$.

performance, there is the need of DM availability which allows the animal to choose for a greater nutritional value feed, increasing roughage intake.

The average DM mass of $4,717 \mathrm{~kg} / \mathrm{ha}$ in the rainy-dry transition period (Table 2) which corresponded to $72.8 \mathrm{~g} / \mathrm{kg}$ of $\mathrm{BW}$ is within the range from 70 to $110 \mathrm{~g} / \mathrm{kg} \mathrm{BW}$ of forage supply to obtain high DWG without affecting gain per area (Barbosa et al., 2006).

Due to recognized seasonality of "qualitativequantitative" production of tropical forages, to define grazing management strategies based on the pasture condition shall establish management targets for each season, and in the dry season, the morphological differentiation and living with senescence should be minimized (Paulino et al., 2008). The DM average mass of $3,016 \mathrm{~kg} / \mathrm{ha}$, during the dry season, accounted for $42.8 \mathrm{~g} / \mathrm{kg}$
BW of heifers (Table 2).

For Paulino et al. (2008), the interpretation of forage available for grazing as baseline nutritional resource should be conducted from the perspective of the fraction potentially convertible into animal product, which can be achieved by applying the concept of DMpd, as it contains the quantity and quality regardless of season. In the rainydry transition, an average of 2,742 kg/ha of DMpd (Table 2), which corresponded to a supply of $42.4 \mathrm{~g} / \mathrm{kg}$ BW was observed and it is within the recommendation of Paulino et al. (2004) of 40 to $50 \mathrm{~g} / \mathrm{kg} \mathrm{BW}$ of animals of DMpd of pasture for a satisfactory performance. However, in the dry season the DMpd fraction was $1,533 \mathrm{~kg} / \mathrm{ha}(21.7 \mathrm{~g} / \mathrm{kg} \mathrm{BW})$ (Table 2), which is half of the minimum recommended by this author.

As dry period advanced, percentage of dry leaf blade

Table 8. Parameterization of total apparent digestibility in heifers under grazing supplemented with protein supplement according to linear-response-plateau function

\begin{tabular}{lccccccc}
\hline \multirow{2}{*}{ Item } & \multicolumn{2}{c}{ Linear phase } & & & \multicolumn{2}{c}{ Plateau } \\
\cline { 2 - 3 } & Intercept & Slope & & MS level $^{1}$ & & Estimate & $\mathrm{R}^{2}$ \\
\hline Dry matter & 52.5417 & 9.4100 & & 1.1072 & & 62.9600 & 0.9716 \\
Organic matter & 56.1800 & 12.9400 & & 0.8511 & & 67.1933 & 0.9870 \\
Crude protein & 29.9800 & 45.1000 & & 0.8044 & & 66.2600 & 0.9915 \\
Ether extract & 22.0700 & 59.5800 & & 0.8187 & & 70.8500 & 0.9803 \\
Non-fibrous carbohydrates & 47.1800 & 25.4000 & & 1.2514 & & 78.9667 & 0.9623 \\
Total digestible nutrients & 53.3267 & 11.3600 & & 1.1323 & & 66.1900 & 0.9696 \\
\hline
\end{tabular}

${ }^{1}$ Level of protein supplement supply in which estimates of digestibility are stabilized (plateau). 
Table 9. Nitrogenous compounds metabolism in heifers according to the different treatments

\begin{tabular}{|c|c|c|c|c|c|c|c|c|c|c|}
\hline \multirow{2}{*}{ Item } & \multicolumn{5}{|c|}{ Protein supplement $(\mathrm{kg} / \mathrm{d})$} & \multirow{2}{*}{$\begin{array}{l}\mathrm{CV} \\
(\%)\end{array}$} & \multicolumn{4}{|c|}{ p-value $^{1}$} \\
\hline & 0 & 0.5 & 1.0 & 1.5 & 2.0 & & $\mathrm{~L}$ & $\mathrm{Q}$ & $\mathrm{C}$ & $\mathrm{F}$ \\
\hline \multicolumn{11}{|c|}{ Rainy-dry transition season } \\
\hline $\mathrm{UNUE}^{2}$ & 26.18 & 28.25 & 57.71 & 65.30 & 71.51 & 24.6 & $<0.0001$ & 0.5012 & 0.1135 & 0.1500 \\
\hline FMNC & 84.11 & 87.84 & 88.70 & 88.19 & 83.26 & 10.7 & 0.9224 & 0.2968 & 0.9090 & 0.9193 \\
\hline $\mathrm{MSE}^{3}$ & 135.92 & 144.40 & 123.71 & 110.46 & 104.18 & 17.6 & 0.0070 & 0.5903 & 0.2607 & 0.6963 \\
\hline $\mathrm{FMNC} \mathrm{NI}^{4}$ & 1.04 & 0.92 & 0.73 & 0.61 & 0.53 & 17.8 & $<0.0001$ & 0.5626 & 0.6047 & 0.7576 \\
\hline \multicolumn{11}{|l|}{ Dry season } \\
\hline $\mathrm{UNUE}^{5}$ & 12.08 & 24.45 & 47.60 & 49.92 & 76.16 & 30.8 & $<0.0001$ & 0.7940 & 0.5173 & 0.1864 \\
\hline FMNC $^{6}$ & 67.19 & 65.65 & 65.84 & 70.69 & 74.33 & 8.1 & 0.0280 & 0.1318 & 0.7055 & 0.6696 \\
\hline $\mathrm{MSE}^{7}$ & 180.29 & 130.95 & 113.55 & 118.51 & 118.68 & 12.4 & $<0.0001$ & 0.0004 & 0.1227 & 0.7746 \\
\hline $\mathrm{FMNC} \mathrm{NI}^{8}$ & 1.59 & 0.94 & 0.73 & 0.62 & 0.62 & 14.9 & $<0.0001$ & $<0.0001$ & 0.1944 & 0.5452 \\
\hline
\end{tabular}

UNUE = Ureic nitrogen urinary excretion $(\mathrm{g} / \mathrm{d})$. FMNC $=$ Flow of microbial nitrogen compounds $(\mathrm{g} / \mathrm{d})$.

MSE $=$ Microbial synthesis efficiency $(\mathrm{g}$ microbial CP/kg TDN).

$\mathrm{FMNC} / \mathrm{NI}=$ Flow of microbial nitrogen compounds in relation to nitrogen intake ( $\mathrm{g} / \mathrm{g}$ nitrogen intake).

${ }^{1} \mathrm{~L}, \mathrm{Q}, \mathrm{C}$, and $\mathrm{F}=$ Linear, quadratic, cubic and fourth degree, respectively.

${ }^{2} \hat{Y}=26.1+23.0230 x\left(r^{2}=0,8782\right) .{ }^{3} \hat{Y}=140.51-14.1548 x\left(r^{2}=0.7602\right) .{ }^{4} \hat{Y}=1.05-0.2333 x\left(r^{2}=0.9943\right) ;{ }^{5} \hat{Y}=12.67+10.4092 x\left(r^{2}=0.9123\right)$

${ }^{6} \hat{\mathrm{Y}}=64.87+3.8658 \mathrm{x}\left(\mathrm{r}^{2}=0.6743\right) .{ }^{7} \hat{\mathrm{Y}}=176.87-96.4883 \mathrm{x}+34.6778 \mathrm{x}^{2}\left(\mathrm{R}^{2}=0.9540\right) .{ }^{8} \hat{\mathrm{Y}}=1.55-1.24 \mathrm{x}+0.3990 \mathrm{x}^{2}\left(\mathrm{R}^{2}=0.9818\right)$.

and dry stem+sheath increased, that is, dead material and with less nutritional value. According to Cabral et al. (2011), of the structural characteristics of canopy, only the mass of green forage, consisting of green leaf blade and green stem+sheath, presents a strong and positive correlation with the performance of animals.

Daily weight gain presented a quadratic effect $(\mathrm{p}<0.10)$ for the different levels of protein supplementation (Table 3). The maximum DWG of $489.4 \mathrm{~g}$ occurred for the supply level of $1.05 \mathrm{~kg}$ of supplement per animal per day and performance was approximately $32 \%$ higher than that of heifers fed only mineral supplement.

Maximum performance DWG was similar to that found by Barros et al. (2011a), offering $1.0 \mathrm{~kg} / \mathrm{d}$ of supplement with $250 \mathrm{~g} \mathrm{CP} / \mathrm{kg}$ for heifers in Brachiaria decumbens in the rainy-dry transition season. On the other hand, Moraes (2010), supplementing heifers with supplement with $400 \mathrm{~g}$ $\mathrm{CP} / \mathrm{kg}$ at a rate of $840 \mathrm{~g} / \mathrm{animal} / \mathrm{d}$ during the same season, found ADG of $478 \mathrm{~g}$.

The average content of $72 \mathrm{~g} \mathrm{CP} / \mathrm{kg}$ forage DM (Table 1) is the minimum limit necessary to maintain microbial growth and to promote digestion of low quality forage fibrous carbohydrates, as reported by Lazzarini et al. (2009), but it is below the level of $10 \mathrm{~g} \mathrm{CP} / \mathrm{kg}$ (Lazzarini et al., 2009; Sampaio et al., 2009) that optimizes the utilization of forage energy substrates, explaining the lower performance of animals fed only mineral supplement. The additional supply of protein via supplementation optimizes the performance of animals, highlighting the importance of its use, because in addition to nitrogen compounds deficiency, which has priority nature, nutritional deficiencies are of multiple nature.

The DWG had a quadratic effect $(\mathrm{p}<0.10)$ for levels of protein supplementation (Table 3) in the dry season. However, by analyzing the standard description of the least square means, a decrease in efficiency of weight gain $(\mathrm{g} / \mathrm{kg}$ of supplement) was observed when level of protein supplement supply was increased (Table 4), with a tendency to stabilize DWG.

Thus, adjustment with non-linear regression model was done, as it follows:

$$
\mathrm{DWG}=\mathrm{G}_{0}+\Delta \times\left(1-\mathrm{e}^{-\mathrm{k} \times \mathrm{N}}\right)
$$

In which:

$\mathrm{G}_{0}=$ daily weight gain with no supplementation $(\mathrm{g} / \mathrm{d})$;

$\Delta=$ increment potential in weight gain considering the experimental conditions of this study $(\mathrm{g} / \mathrm{d})$;

$\mathrm{k}=$ fractional rate of alteration in the DWG in function

Table 10. Parameterization of nitrogenous compounds metabolism in heifers under grazing supplemented with protein supplement according to linear-response-plateau function

\begin{tabular}{lccccccc}
\hline \multirow{2}{*}{ Item } & \multicolumn{2}{c}{ Linear phase } & & \multicolumn{3}{c}{ Plateau } \\
\cline { 2 - 3 } & Intercept & Slope & & SM level ${ }^{1}$ & Estimate & $\mathrm{R}^{2}$ \\
\hline MSE & 180.2900 & -98.6800 & & 0.6422 & 116.9133 & 0.9943 \\
FMNC/NI & 1.5876 & -1.2870 & & 0.7218 & 0.6586 & 0.9890 \\
\hline
\end{tabular}

MSE = Microbial synthesis efficiency (g microbial CP/kg TDN).

$\mathrm{FMNC} / \mathrm{NI}=$ Flow of microbial nitrogen compounds in relation to nitrogen intake (g/g nitrogen intake).

${ }^{1}$ Level protein supplement supply in which estimates of MSE and NMICR are stabilized (plateau). 
of supplement mass $\left(\mathrm{kg}^{-1}\right)$;

$\mathrm{N}=$ supplement mass $(\mathrm{kg})$.

By using the lower limit defined by the properties of the confidence interval of $0.90\left(\mathrm{IC}_{0.90}\right)$ of the parameters of the adjusted function, the responses in productive performance were stabilized $(\mathrm{p}>0.10)$ from the supply of $0.98 \mathrm{~kg}$ of protein supplement per day (Figure 1). So, this is the point where DWG becomes equivalent $(p>0.10)$ to the theoretical maximum average gain $\left(D_{W G} G_{M a x}=G_{0}+\Delta\right)$.

Couto et al. (2010) evaluated the productive performance of growing heifers in Brachiaria decumbens Stapf pastures, with starchy or fibrous source supplementation and observed a greater DWG of animals under supplementation than those fed only mineral $(0.198$ vs $0.077 \mathrm{~kg} / \mathrm{animal} / \mathrm{d}$ ). Despite the small DWG of animals in the control treatment, there was no weight loss as observed in this work, because the availability of DM and pasture content of CP content was $5,013 \mathrm{~kg} / \mathrm{ha}$ and 83.1 $\mathrm{g} / \mathrm{kg}$, respectively, which were higher than the presented here.

Despite the higher levels of supplementation supplied in this work, feeding continued to be based on pasture. Thus, the poor quality-quantity of forage affected negatively the occurrence of significant gains. This can be confirmed by comparing with the data of Valente et al. (2011), in which growing heifers on pasture with the availability of $2,560 \mathrm{~kg}$ of $\mathrm{DMpd} / \mathrm{ha}$ in the dry period consumed $1,214 \mathrm{~kg}$ of supplement per day with $400 \mathrm{~g} \mathrm{CP} / \mathrm{kg}$ and presented DWG of $307 \mathrm{~g}$.

Increasing linear effect $(\mathrm{p}<0.10)$ of the levels of protein supplement supply were observed for intakes of DM, OM, $\mathrm{CP}, \mathrm{EE}, \mathrm{NFC}$, and TDN, and there was no effect ( $\mathrm{p}>0.10)$ for intakes of pasture DM (PDM), pasture OM (POM), NDFap and iNDF (Tables 5 and 6).

The increasing profiles of intakes of CP, EE and NFC occurred by increasing supplement supply in the different treatments and this was the largest source of these nutrients (Table 1) comparatively to pasture. In contrast, intakes of NDFap, digested neutral detergent fiber (dNDF) and iNDF

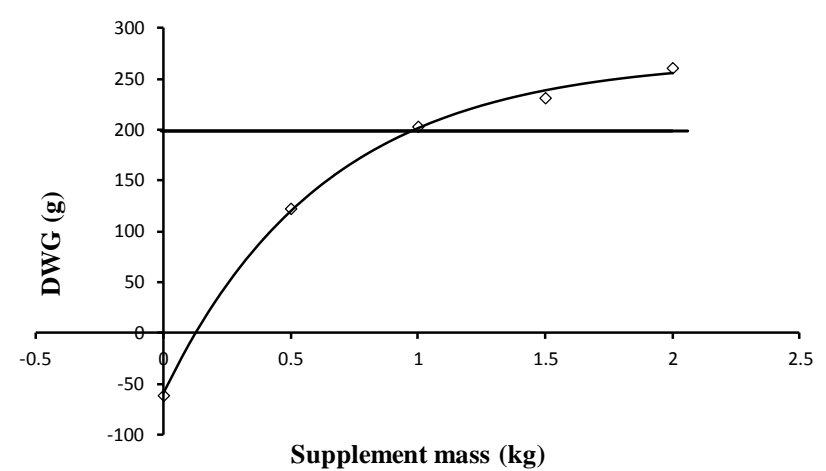

Figure 1. Relationship between daily weight gain (DWG, g) and mass $(\mathrm{kg})$ of the protein supplement consumed by experimental animals $\left(\hat{\mathrm{Y}}=-59.1+329.4 \times\left(1-\mathrm{e}^{-1.5706 \times \mathrm{N}}\right) ; \mathrm{R}^{2}=0.9857\right)$. showed the same profile ( $p>0.10$ ) of PDM intake (Tables 5 and 6), as the primary source of these fractions was pasture.

The linear effect on intake of DM and OM and the no effect for intakes of PDM and POM show that there was no substitution effect of supplement intake on forage intake which would be positive if the performance was also increasing linear, which did not occur. This context drives to the possibility of a nutritional imbalance in the rainy-dry season.

The average intake of PDM was $12.4 \mathrm{~g} / \mathrm{kg} \mathrm{BW}$, in the dry season, which was lower than $20.84 \mathrm{~g} / \mathrm{kg} \mathrm{BW}$ (Couto et al., 2010) and $20.66 \mathrm{~g} / \mathrm{kg} \mathrm{BW}$ (Valente et al., 2011) found in previous works because the low forage mass in all experimental periods did not allow maximization of PDM intake, making the effects of protein supplementation on intake less evident.

The positive linear pattern for TDN intake with protein supplementations (Table 6) seems to reflect the increase in consumption and coefficients of digestibility (Table 7) of $\mathrm{CP}$, EE, and NFC, with no significant increase in the extraction of energy from NDFap because there was no effect on the consumption of digested NDF (dNDF) (Tables 5 and 6). This pattern is consistent with that observed by Lazzarini (2011).

Results obtained in tropical conditions with low quality forages indicate that direct responses on total consumption or digested components are obtained by supplementation with nitrogen compounds up to levels of 80 to $100 \mathrm{~g} \mathrm{CP} / \mathrm{kg}$ in the diet (Lazzarini et al., 2009; Detmann et al., 2010; Figueiras et al., 2010). From this point, the response to this type of supplementation become little evident on consumption and the losses of nitrogen compounds become more prominent (Detmann et al., 2009).

Thus, it was expected an increase in NDFap and dNDF intakes by increasing the level of supplementation, however, this did not occur, probably by restricting the mass of pasture DM. The average intake of NDFap observed in this study was $9.7 \mathrm{~g} / \mathrm{kg} \mathrm{BW}$, which is lower than that observed by other authors during the dry season (Moraes et al., 2009; Figueiras et al., 2010; Moraes et al., 2010; Lazzarini, 2011), indicating that consumption of the pasture was not optimized.

Figure 2 shows the relationship TDN/CP according to the level of protein supplement intake by heifers in different treatments in the rainy-dry transition season.

Even in tropical conditions, with the use of low quality basal resources, the regulation of voluntary intake cannot be defined exclusively by a single regulatory mechanism; physical mechanisms such as ruminal fill work together with physiological and metabolic mechanisms (Detmann et al., 2003).

The ratio of metabolizable protein and metabolizable energy, $r$ epresented in Figure 2 by the relation TDN/CP, is one of the intake determinant factors (Illius and Jessop, 


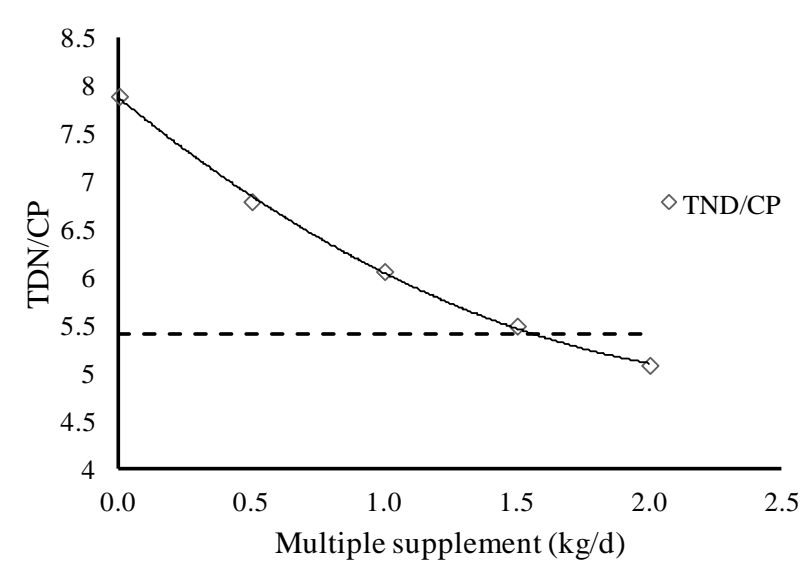

Figure 2. Relationship between total digestible nutrients and crude protein (TDN/CP) acording to protein supplemement intake in the different treatments in the rainy-dry season. Dotted line is TDN/CP relationship dictated by nutritional requirement for maintainance and $0.5 \mathrm{~kg} / \mathrm{d}$ gain according to data by Valadares Filho et al. (2010).

1996), and the adjustments made by the animal to increase or decrease the use of fiber (digestibility of NDFap, Table 7) and decrease in consumption indicates adaptive mechanisms for reduction of discomfort factors by excess of energy in the diet (Forbes, 2003). In these cases, the excess of energy would be eliminated by futile cycles in animal metabolism (Leng, 1990; Poppi and McLennan, 1995).

According to Valadares Filho et al. (2010), the relationship TDN/CP dictated by nutritional requirements for maintenance and gain of $0.5 \mathrm{~kg} / \mathrm{d}$ (Figure 2) is 5.3, close to that found in this work for higher DWG.

In this context, at the two extremes of the relationship TDN/CP (Table 5 and Figure 2) a decrease in performance (Table 3) was observed, explaining the quadratic behavior with the different levels of protein supplement feeding in the rainy-dry transition season. It is noteworthy that Detmann et al. (2010) analyzed forage harvested in tropical pastures under continuous management and found that most of the data presented relationship TDN/CP above those demanded by the animals. Supplementation led to an increase of $\mathrm{CP}$ content in the diet which increased dietary balance and enabled higher ADG.

In the rainy-dry transition season the levels of protein suplementation had an increasing linear effect $(p<0.10)$ on coefficients of apparent digestibility of OM, CP, EE, NFC, and TDN and apparent digestibility of DM was not different ( $>0.10$ ) among treatments (Table 7).

The digestibility of CP, NFC and EE showed increasing linear profiles due to the effect of dilution of fecal metabolic fraction resulting from increased consumption of these fractions with the increased supply of protein supplement (Tables 5 and 7). Additionally, the apparent digestibility of the protein may have been enlarged for greater losses of rumen $\mathrm{N}$ (Barros et al., 2011b). The microorganisms obtain $\mathrm{N}$ from the diet and recycled, resulting in a decrease in the proportion of endogenous $\mathrm{N}$ in fecal nitrogen compounds as $\mathrm{N}$ intake increases (Valadares et al., 1997; Cabral et al., 2006).

In the dry season there was a quadratic effect $(\mathrm{p}<0.10)$ of levels of protein supplement on digestibility of DM, OM, $\mathrm{CP}, \mathrm{EE}, \mathrm{NFC}$, and TDN (\% DM) and there was no effect on the digestibility of NDFap ( $p>0.10)$ (Table 7).

However, when evaluating the means of digestibility of the different fractions, a linear-response-plateau (LRP) standard was suggest. The adjustment of these functions evidenced (Table 8$)$ the increase $(\mathrm{p}<0.10)$ of digestibilities of DM, OM, CP, EE, NFC, and TDN with limits close to $1.1,0.9,0.8,0.8,1.3$, and $1.1 \mathrm{~kg}$ of protein supplement per day, respectively. From these levels, the mentioned variables remained unchanged.

It is noteworthy that by calculating the means of the levels of the protein supplement which constituted the digestibility plateau of the different feed fractions, the average value of $0.98 \mathrm{~kg}$ which corresponds to the point where DWG becomes equivalent to $\mathrm{DWG}_{\mathrm{Max}}$ is found.

The ureic nitrogen urinary excretion (UNUE, g/d) showed a positive linear $(\mathrm{p}<0.10)$ profile for levels of supplementation (Table 9). Urea is the excretion of nitrogen (N) metabolism by mammals, which occurs with energy expenditure. Therefore, as the level of supplementation was increased, there was an increase in the loss of $\mathrm{N}$.

There was no effect of supplementation levels on the flow of microbial nitrogen compounds (FMNC, g/d) $(\mathrm{p}>0.10)$, but the microbial synthesis efficiency (MSE, $g$ microbial $\mathrm{CP} / \mathrm{kg}$ TDN consumed), and the flow of microbial nitrogen compounds in relation to nitrogen intake (FMNC/NI, g/g nitrogen intake) showed negative linear profiles $(\mathrm{p}<0.10)$ in the rainy-dry season (Table 9$)$.

The no-effect of levels of supplementation on flow of FMNC is in agreement with the NRC (2001), because in situations in which there is lack of nitrogen compounds in the rumen, there is a net gain of nitrogen in the system via recycling.

Lazzarini et al. (2009), Sampaio et al. (2010), Figueiras et al. (2010) and Souza et al. (2010) also found no effect of supplementation in tropical conditions on the FMNC. The average FMNC of $86.42 \mathrm{~g} / \mathrm{d}$ of this work is close to the value of $85.98 \mathrm{~g} / \mathrm{d}$ found by Barros et al. (2011b).

The linear negative effect of supplementation levels on the MSE is not due to lower microbial production but to the increased consumption of TDN (Table 5), in as much as MSE is the ratio between the production of microbial CP and TDN intake $(\mathrm{kg})$.

Control animals showed FMNC/NI of 1.04 indicating protein deficit in the diet and recycling of $\mathrm{N}$ to maintain the microbial activity in the rumen. In the rainy-dry transition 
season, estimates of variables $\mathrm{N}$ ingestion and production of microbial nitrogen became equivalent at the level of $0.22 \mathrm{~kg}$ of protein supplement supply, which corresponded to a diet of $81.6 \mathrm{~g} \mathrm{CP} / \mathrm{kg}$. This result shows that a large part of the nitrogen compounds required by rumen microorganisms can be attributed to recycling of the dietary urea when CP levels of diet are below $81.6 \mathrm{~g} / \mathrm{kg}$.

There was an increasing linear effect $(\mathrm{p}<0.10)$ of the levels of protein supplement supply on FMNC in the dry season (Table 9). The highest supplement intake increased the availability of nitrogen and readily available energy for microbial assimilation, as described by Valente et al. (2011), explaining the increasing linear effect on the FMNC.

The MSE and the FMNC/NI presented quadratic profiles $(\mathrm{p}<0.10)$ in function of the different treatments in the dry season (Table 9). However, when evaluating the least squares mean, the standard $L R P$ was observed for MSE and FMNC/NI (Table 10). Functions adjustment evidenced the linear decreasing profile of MSE and FMNC/NI up to the values of 116.9 and 0.65 , respectively. From these points, the variables remained unchanged.

The estimate of the MSE in the control treatment was greater than the theoretical value suggested by Valadares Filho et al. (2010) for tropical conditions, because the deficiencies of nitrogen compounds in the diet caused a net gain of nitrogen in the rumen by a greater representation of the recycling events, which involve the increase in microbial efficiency (NRC, 2001).

Thus, the control animals showed FMNC/NI of 1.58, indicating strong protein deficit in the diet and recycling of $\mathrm{N}$ to maintain the microbial activity in the rumen. In the dry season, the equivalence between $\mathrm{N}$ intake and production of microbial nitrogen compounds occurred at level of $0.63 \mathrm{~kg}$ of daily supply level of protein supplement $(89 \mathrm{~g} \mathrm{CP} / \mathrm{kg}$ DM).

\section{CONCLUSIONS}

It is concluded that supplementation improves the productive performance of grazing heifers and that $1.0 \mathrm{~kg} / \mathrm{d}$ of supplement per animal gives the maximum increment of weight gain.

\section{REFERENCES}

Barbosa, A. M., R. F. D. Valadares, S. C. Valadares Filho, D. S. Pina, E. Detmann, and M. I. Leão. 2011. Endogenous fraction and urinary recovery of purine derivatives obtained by different methods in Nellore cattle. J. Anim. Sci. 89:510-519.

Barbosa, M. A. A. F., D. Nascimento Jr., and U. Cecato. 2006. Pasture dynamic and performance of steers in Panicum maximum Jacq. cv. Tanzânia under different forage allowances. R. Bras. Zootec. 35:1594-1600.

Barros, L. V., M. F. Paulino, E. Detman, S. C. Valadares Filho, S.
A. Lopes, A. A. Rocha, É. E. L. Valente, and D. M. Almeida. 2011a. Replacement of soybean meal by treated castor meal in supplements for grazing heifer during the dry-rainy season period. R. Bras. Zootec. 40:843-851.

Barros, L. V., M. F. Paulino, S. C. Valadares Filho, E. Detmann, F. G. Silva, É. E. L. Valente, S. A. Lopes, and L. S. Martins. 2011b. Replacement of soybean meal by cottonseed meal 38\% in multiple supplements for grazing beef heifers. R. Bras. Zootec. 40:852-859.

Cabral, C. H. A., M. O. Bauer, R. C. Carvalho, C. E. A. Cabral, and W. B. Cabral. 2011. Steers performance and economical viability supplemented in the rainy season. Rev. Caatinga. 24:173-181.

Cabral, L. S., S. C. Valadares Filho, E. Detmann, P. A. M. Malafaia, J. T. Zervoudakis, A. L. Souza, R. G. Veloso, and P. M. M. Nunes. 2006. Intake and digestibility in cattle fed tropical forage based diets. R. Bras. Zootec. 35:2406-2412.

Chen, X. B. and M. J. Gomes. 1992. Estimation of microbial protein supply to sheep and cattle basid on urinary excretion of purine derivatives - an overview of the technical details. International Feed Resources Unit, Rowett Research Institute, Ocasional Publication, Ed. Buchsburnd Aberdeen, UK. p. 21.

Chizzotti, M. L., S. C. Valadares Filho, R. F. Valadares, F. H. M. Chizzotti, J. M. S. Campos, M. I. Marcondes, and M. A. Fonseca. 2006. Intake, digestibility and urinary excretion of urea and purine derivatives in heifers with different body weights. R. Bras. Zootec. 35:1813-1821.

Couto, V. R. M., M. F. Paulino, E. Detmann, S. C. Valadares Filho, M. F. L. Sales, L. V. Barros, M. O. Porto, and É. E. L. Valente. 2010. Energy sources and supplementation levels for beef heifers raised during the dry season. R. Bras. Zootec. 39:24942501.

Detmann, E. and S. C. Valadares Filho. 2010. On the estimation of non-fibrous carbohydrates in feeds and diets. Arq. Bras. Med. Vet. Zootec. 62:980-984.

Detmann, E., M. F. Paulino, and S. C. Valadares Filho. 2010. Optimizing the use for basal forage resources. In: Symposium of Beef Cattle Production. 7. International Symposium of Beef Cattle Production, 3. University Federal of Viçosa, Viçosa, MG, Brazil. pp. 191-240.

Detmann, E., M. F. Paulino, H. C. Mantovani, S. C. Valadares Filho, C. B. Sampaio, M. A. Souza, I. Lazzarini, and K. S. C. Detmann. 2009. Parameterization of ruminal fiber degradation in low-quality tropical forage using Michaelis-Menten kinetics. Livest. Sci. 126:136-146.

Detmann, E., A. C. Queiroz, P. R. Cecon, J. T. Zervoudakis, M. F. Paulino, S. C. Valadares Filho, L. S. Cabral, and R. P. Lana. 2003. Neutral detergent fiber intake by feedlot cattle. R. Bras. Zootec. 32:1763-1777.

Detmann, E., M. F. Paulino, J. T. Zervoudakis, S. C. Valadares Filho, R. F. Euclydes, R. P. Lana, and D. S. Queiroz. 2001. Chromium and internal markers in intake determination by crossbred steers, supplemented at pasture. R. Bras. Zootec. 30:1600-1609.

Figueiras, J. F., E. Detmann, M. F. Paulino, T. N. P. Valente, S. C. Valadares Filho, and I. Lazzarini. 2010. Intake and digestibility in cattle under grazing supplemented with nitrogenous compounds during dry season. R. Bras. Zootec. 39:1303-1312.

Forbes, J. M. 2003. The multifactorial nature of food intake 
control. J. Anim. Sci. 81:E139-E144.

Illius, A. W. and N. S. Jessop. 1996. Metabolic Constraints on voluntary intake in ruminants. J. Anim. Sci. 74:3052-3062.

Johnson, A. D. 1978. Sample preparation and chemical analisys of vegetation. In: Measurement of Grassland Vegetation and Animal Production (Ed. L. T. Manejte). Aberustwysth: Commonweath Agricultural Bureax, p.96-102.

Lazzarini, I. 2011. Nutritional Performance of Cattle under Grazing during Dry and Rainy Seasons Supplemented with Nitrogenous Compounds and/or Starch. Ph.D. Thesis. University Federal of Viçosa, Viçosa, MG, Brazil. p. 66.

Lazzarini, I., E. Detmann, C. B. Sampaio, M. F. Paulino, S. C. Valadares Filho, M. A. Souza, and F. A. Oliveira. 2009. Intake and digestibility in cattle fed low-quality tropical forage and supplemented with nitrogenous compounds. R. Bras. Zootec. 38:2021-2030.

Leng, R. A. 1990. Factors affecting the utilization of "poorquality" forages by ruminants particularly under tropical conditions. Nut. Res. Review. 3:277-303.

Licitra, G., T. M. Hernandez, and P. J. Van Soest. 1996. Standardization of procedures for nitrogen fractionation of ruminant feeds. Anim. Feed Sci. Technol. 57:347-358.

Maquivar, M., and M. L. Day. 2009. Nutritional regulation of puberty. In: Course New Approaches of Production and Reproduction of Cattle, 13. Uberlândia, MG, Brazil. Uberlândia: UNESP. pp. 143-158.

Moraes, A. L. 2010. Performance of Nelore Heifers Subjected to Levels of crude protein in the rainy-dry transition period. (Master's Thesis). 55 p. University of São Paulo, SP, Brazil.

Moraes, E. H. B. K., M. F. Paulino, S. C. Valadares Filho, K. A. K. Moraes, E. Detmann, and M. G. Souza. 2010. Nutritional evaluation of supplementation strategies for beef cattle during the dry season. R. Bras. Zootec. 39:608-616.

Moraes, E. H. B. K., M. F. Paulino, K. A. K. Moraes, S. C. Valadares Filho, J. T. Zervoudakis, and E. Detmann. 2009. Urea in protein-energy supplements for beef cattle during the dry season: nutritional and ruminal traits. R. Bras. Zootec. 38:770-777.

Mertens, D. R. 2002. Gravimetric determination of amylasetreated neutral detergent fiber in feeds with refluxing in beaker or crucibles: collaborative study. J. AOAC Internat. 85:12171240.

National Research Council (NRC). 2001. Nutrients Requirements of Dairy Cattle. National Academy Press. Washington, DC, p. 381.

Paulino, M. F., E. Detmann, and S. C. Valadares Filho. 2008. Functional cattle in the tropics. In: Symposium of Beef Cattle Production, 6. International Symposium of Beef Cattle Production, 2. University Federal of Viçosa, Viçosa, MG, Brazil. pp. 275-305.

Paulino, M. F., D. M. Figueiredo, E. H. B. K. Moraes, M. O. Porto, M. F. L. Sales, T. S. Acedo, S. D. J. Villela, and S. C. Valadares Filho. 2004. Supplementation of cattle in pastures: a systemic view. In: Symposium of Beef Cattle Production, 4. University Federal of Viçosa, Viçosa, MG, Brazil. pp. 93-139.

Poppi, D. P. and S. R. McLennan. 1995. Protein and energy utilization by ruminants at pasture. J. Anim. Sci. 73:278-290.

Rigolon, L. P., I. N. Prado, F. L. B. Cavalieri, J. A. Negrão, R. R.
Silva, and J. A. Marques. 2008. Levels of dry matter intake on metabolites and hormones plasmatic and follicular hormones in beef heifers. Rev. Bras. Saúde Prod. An. 9:367-383.

Sá Filho, M. F., L. U. Gimenes, J. N. S. Sales, G. A. Crepaldi, A. G. Medalha, and P. S. Baruselli. 2008. Artificial insemination in heifers. In: International Symposium on Applied Animal Reproduction, 3. State University of Londrina, Londrina, PR, Brazil. pp. 54-67.

Sampaio, C. B., E. Detmann, M. F. Paulino, S. C. Valadares Filho, M. A. Souza, I. Lazzarini, P. V. Paulino, and A. C. Queiroz. 2010. Intake and digestibility in cattle fed low-quality tropical forage and supplemented with nitrogenous compounds. Trop. Anim. Health Prod. 42:1471-1479.

Sampaio, C. B., E. Detmann, I. Lazzarini, M. A. Souza, M. F. Paulino, and S. C. Valadares Filho. 2009. Rumen dynamics of neutral detergent fiber in cattle fed low-quality tropical forage and supplemented with nitrogenous compounds. R. Bras. Zootec. 38:560-569.

Santos, J. E. and M. Amstalden. 1998. Effects of nutrition on bovine reproduction. In: Arq. Facul. Vet. 26. Atibaia, SP, Brazil. pp. 19-79.

Semmelmann, C. E. N., J. F. P. Lobato, and M. G. Rocha. 2001. Effect of feeding systems on weight gain and reproductive performance of Nellore heifers bred at the age of 17/18 months. Rev. Bras. Zootec. 30:835-843.

Silva, D. J. and A. C. Queiroz. 2002. Food analysis: Chemical and biological methods. University Federal of Viçosa, Viçosa, MG, Brazil. p. 235.

Souza, M. A., E. Detmann, M. F. Paulino, C. B. Sampaio, I. Lazzarini, and S. C. Valadares Filho. 2010. Intake, digestibility and rumen dynamics of neutral detergent fiber in cattle fed low-quality tropical forage and supplemented with nitrogen and/or starch. Trop. Anim. Health Prod. 42:1299-1310.

Titgemeyer, E. C, C. K. Armendariz, D. J. Bindel, R. H. Greenwood, and C. A. Loest. 2001. Evaluation of titanium dioxide as a digestibility marker for cattle. J. Anim. Sci. 79:1059-1063.

Valadares, R. F. D., L. C. Gonçalves, I. B. Sampaio, N. M. Rodriguez, and J. F. C. Silva. 1997. Protein levels in cattle diet. 2. Intake, digestibilities and nitrogen balance. R. Bras. Zootec. 26:1259-1263.

Valadares, R. F. D., G. A. Broderick, S. C. Valadares Filho, and M. K. Clayton. 1999. Effect of replacing alfalfa silage with high moisture corn on ruminal protein synthesis estimated from excretion of total purine derivatives. J. Dairy Sci. 82:26862696.

Valadares Filho, S. C., M. I. Marcondes, M. L. Chizzotti, and P. V. R. Paulino. 2010. Nutritional requirements of pure and crossbred zebu BR-CORTE. University Federal of Viçosa , Viçosa, MG, Brazil. p. 193.

Valente, E. E. L., M. F. Paulino, E. Detmann, S. C. Valadares Filho, L. V. Barros, T. S. Acedo, V. R. M. Couto, and S. A. Lopes. 2011. Levels of multiple supplements or nitrogen salt for beef heifers in pasture during the dry season. R. Bras. Zootec. 40:2011-2019.

Williams, C. H., D. J. David, and O. Iisma. 1962. The determination of chromic oxide in faeces samples by atomic absorption spectrophotometry. J. Agric. Sci. 59:381-385. 